\title{
Pengaruh Bimbingan Kelompok Teknik Modelling Untuk Meningkatkan Self-Efficacy Mahasantri
}

\author{
Rizky Faridatul Latifah ${ }^{1}$, Febranti Putri Navion ${ }^{2}$ \\ ${ }^{1}$ Universitas Islam Negeri Sayyid Ali Rahmatullah Tulungagung \\ ${ }^{2}$ Universitas Islam Negeri Sayyid Ali Rahmatullah Tulungagung
}

\begin{tabular}{l} 
Article Info \\
Article history: \\
Received Jan $12^{\text {th }}, 2021$ \\
Revised Feb $20^{\text {th }}, 2021$ \\
Accepted Apr $26^{\text {th }}, 2021$ \\
\hline Keyword: \\
Self-Efficacy, Teknik Modelling, \\
Mahasantri
\end{tabular}

Mahasantri

\begin{abstract}
ABSTRAK
Penelitian ini dilatarbelakangi berbagai macam permasalahan yang dialami oleh mahasantri. Padatnya kegiatan pesantren, tugas akademik kampus dan hambatan-hambatan lain, dapat menimbulkan kurangnya keyakinan diri untuk melangkah maju sehingga menghambat produktifitas mahasantri. Tujuan yang akan dicapai dalam penelitian ini adalah untuk mengetahui pengaruh bimbingan kelompok teknik modelling dalam meningkatkan self-efficacy mahasantri. Metode yang dipilih adalah kuantitatif eksperimen jenis quasi eksperimental design model nonequivalent control group design. Populasi penelitian ini berjumlah 20 mahasantri dengan sampel 12 mahasantri dengan self-efficacay sedang dan rendah berdasarkan hasil pre-test yang kemudian dilakukan pembagian kelompok yaitu kelompok eksperimen dan kontrol. Metode analisis menggunakan uji paired sample t test, uji independent sample t test dan uji $N$ Gain Score. Perolehan hasil menunjukkan pada signifikansi (2-tailed) $0,000<0,05$ dapat diartikan $\mathrm{H}_{\mathrm{a}}$ diterima dan $\mathrm{H}_{0}$ ditolak. Maka dapat diartikan bimbingan kelompok teknik modelling berpengaruh untuk meningkatkan self-efficacy mahasantri Pondok Pesantren Tahfidzul Qur'an Al-Hidayah Tulungagung.
\end{abstract}

C 2021 The Authors. Published by UIN Sultan Syarif Kasim Riau.

This is an open access article under the CC BY license (https://creativecommons.org/licenses/by/4.0)

\section{Corresponding Author:}

Rizky Faridatul Latifah,

Universitas Islam Negeri Sayyid Ali Rahmatullah Tulungagung

Email: riezcie99@gmail.com

\section{Pendahuluan}

Setiap manusia tentu memiliki berbagai kemampuan dalam dirinya, baik itu kemampuan intelektual maupun kemampuan fisik. Pada dasarnya setiap orang memiliki kemampuan yang tidak sama dan memiliki cara tersendiri dalam menjalaninya. Dengan kemampuan yang berbeda-beda seseorang bisa belajar untuk berkembang dalam segala hal, termasuk dalam mengatasi berbagai permasalahan. Namun tidak sedikit orang yang kurang yakin akan kemampuan mereka, sehingga muncul rasa tidak percaya diri yang menjadi penghalang bagi seseorang dalam melakukan suatu tindakan atau mengatasi berbagai permasalahan. Permasalahan yang muncul memang tidak luput dengan banyaknya keluhan. Banyaknya aktivitas sehari-hari yang dilakukan bisa saja memicu permasalahan baru, baik yang datang dari dirinya sendiri ataupun lingkungan. Permasalahan ini terkadang menjadikan seseorang kurang dalam mengoptimalkan diri dengan baik yang akan menghambat proses produktifitas mereka. Keadaan ini bisa membuat seseorang kurang yakin akan kemampuan yang dimilikinya. Keyakinan akan kemampuan diri akan menentukan keberhasilan seseorang dalam mencapai tujuan hidupnya (Hurlock, 2003). 
Self-efficacy dapat dipahami suatu kepercayaan diri terhadap keyakinan dirinya bahwa mereka mampu yang dijadikan patokan dalam melakukan sesuatu. Self-efficacy dianggap sebagai respon seseorang terhadap dirinya sendiri untuk mengetahui seberapa optimal dirinya mampu berperan dalam kondisi tertentu (Bandura, 1997). Pada dasarnya seseorang mempunyai self-efficacy yang berbeda pada setiap situasi, dan mereka memiliki cara tersendiri dalam menghadapinya sesuai dengan kemampuan mereka (Jones, 2011). dalam pencapaian sesuatu self-efficacy ikut berperan dalam keyakinan diri akan kemampuan dalam melakukan suatu tindakan atau tugas tertentu (Lestari \& Afifah, 2016). Dengan begitu, self-efficacy menjadi hal penting lantaran persepsi seseorang akan kemampuannya ikut berpengaruh terhadap beberapa tingkah laku yang bervariasi dalam diri seseorang. Dari hasil pemaparan, dapat diperoleh simpulan bahwa tingkah laku setiap individu tidak akan sama saat menghadapi berbagai keadaan yang ada, dan juga semua itu kembali lagi bagaimana mereka menghadapinya. Sebagai mana ketika proses tatap muka pembelajaran para peserta didik. Siswa dengan tingkat efikasi diri tinggi mereka akan memiliki perilaku yang berbeda dalam menjalani aktivitasnya jika dibandingkan dengan mereka pemilik self-efficacy rendah.

Seseorang dengan tingkat self-efficacay tinggi setiap permasalahan yang muncul dapat diatasi dengan keyakinan dan usaha yang keras. Mereka akan terus belajar untuk meningkatkan kemampuan dan belajar dari sebuah permasalahan yang ada. Mereka menganggap sebuah permasalahan sebagai pengalaman yang berharga. Faktor internal yang memiliki peran penting dalam mempengaruhi self-efficacy salah satunya adalah prestasi akademik. Dalam masalah mengerjakan tugas, seseorang pemilik self-efficacy tinggi tidak akan menunda-nunda dan tanggap dalam pengerjaan tugas meskipun tugas tersebut susah. Kemudian mereka mudah percaya dalam menghadapi kejadian dalam situasi tertentu, mereka akan tekun pada setiap tugas dan hanya mengharapkan kesuksesan dalam menghadapi rintangan. Tapi sebaliknya jika seseorang memiliki self-efficacy rendah dalam pengerjaan tugas, mereka mudah menunda-nunda pengerjaan tugas sampai tugas tersebut benar-benar akan dikumpulkan. Mereka memandang tugas sebagai beban yang besar bahkan mereka juga tidak mau mencari jalan keluar dari permasalahannya. Ketika menghadapi permasalahan, mereka cenderung lebih banyak mengeluh dari pada bekerja mencari jalan keluar. Kondisi seperti inilah yang akan memunculkan rasa kurang percaya diri pada diri mereka sehingga timbul self-efficacy rendah.

Pada penelitian ini dikuatkan penelitian terdahulu yang telah ada dilaksanakan oleh Navion (2016). Variabel yang signifikan yang mempengaruhi langsung terhadap prestasi akademik adalah efikasi diri akademik. Dalam penelitian tersebut membuktikan bahwa self-efficacy terbukti memiliki pengaruh penting dalam bidang akademik. Seperti halnya seorang mahasiswa, karena dibanding dengan seorang siswa mereka memiliki tugas yang lebih dalam bidang akademisnya. Sebagai seorang mahasiswa seharusnya memiliki self-efficacy yang tinggi. Karena sebagai mahasiswa di institusi pendidikan tertinggi, mereka dituntut untuk menjadi lulusan yang berkompeten dalam bidangnya masing-masing. dengan begitu dapat diartikan bahwa self-efficacy memiliki pengaruh besar guna menunjang proses belajar para peserta didik, baik siswa sekolah dasar hingga perguruan tinggi. Seiring perkembangan zaman maka diperlukan sumber daya manusia unggul yang berbudi pekerti cerdas dan religius. Untuk menghadapi tantangan zaman, para mahasiswa harus memiliki nilai-nilai religius yang dapat mengimbanginya. Kini banyak ditemui mahasiswa yang memiliki peranan ganda yaitu sebagai mahasiswa dan juga sebagai santri atau yang biasa disebut Mahasantri. Mahasantri merupakan seseorang yang sedang memperdalam agama dan akidah di suatu yayasan pondok pesantren dan juga sedang menempuh sekolah diperguruan tinggi. Pondok pesantren mahasiswa sekarang memang sudah banyak ditemui. Dalam sejarah perkembangannya pesantren kian merambah pada perguruan tinggi atau yang biasa disebut pesantren mahasiswa. Seperti halnya di Tulungagung, banyaknya mahasiswa yang mendaftar di UIN Sayyid Ali Rahmatullah Tulungagung juga membuat pesantren mahasiswa kian diminati.

Salah satu pondok pesantren mahasiswa di sekitar UIN Sayyid Ali Rahmatullah Tulungagung adalah Pondok Pesantren Tahfidzul Qur'an Al-Hidayah Plosokandang Tulungagung. Pondok tahfidz AlHidayah dikenal sebagai yayasan pondok pesantren berbasis Al-Qur'an, yang mana pondok tersebut juga ditempati para mahasiswa yang kuliah di UIN SATU Tulungagung. Sebagaimana yang telah disebutkan di awal, mereka memiliki peran ganda sebagai santri dan juga mahasiswa. Padatnya kegiatan di pondok maupun dikampus membuat mereka harus pintar dalam membagi waktu. Apalagi mereka seorang santri tahfidz yang memiliki tuntutan hafalan 30 juz, belum lagi kegiatan pondok yang padat belum lagi tugas akademik yang banyak. Terkadang hal seperti ini yang membuat mereka menjadi kurang yakin akan kemampuannya, merasa terbebani yang menimbulkan permasalahan.

Menjadi seorang mahasantri mereka harus mampu membagi waktu antara kegiatan kampus maupun kegiatan pondok. Selain itu mereka juga menghadapi beberapa hambatan dalam mengerjakan tugas kampus ataupun ketika proses menghafal Al-Qur'an. Hambatan yang sering terjadi biasanya muncul rasa malas, mengantuk karena padatnya kegiatan pondok, kecapekan, menemui kesulitan dalam belajar ataupun kesulitan dalam menghafal Al-Qur'an, hingga sulit membagi waktu. 
Sebagaimana penuturan sebagian mahasantri bahwa dalam menghadapi aktivitasnya baik di pondok ataupun di kampus, mereka sering mengalami hambatan. Biasanya mereka sering merasa kecapekan, muncul rasa malas dalam mengerjakan tugas akademik kampus, terkadang dalam pengerjaan tugas kampus mereka suka mengerjakan mepet waktu pengumpulan, sering menggunakan sistem kebut semalam, malas dalam menghafal Al-Qur'an, mudah lupa dengan hafalannya. Disamping itu mereka juga mengalami rasa bosan, jenuh dalam proses meghafal, terkadang timbul rasa pesimis dengan kemampuannya dalam mengerjakan tugas kampus ataupun dalam menghafal. Hal seperti ini yang membuat para mahasantri kurang yakin dengan kemampuan mereka sehingga mudah putus asa dan kurang bersemangat dalam menjalani aktivitasnya. Keadaan ini jika diteruskan akan menghambat produktivitas mereka dalam mencapai keberhasilan menuju cita-citanya.

Berdasarkan penuturan mereka, peneliti memandang bahwa dalam aktivitas keseharian mahasantri mereka mengalami hambatan-hambatan yang mengganggu proses belajar mereka. Tuntutan hafalan, muroja'ah dan banyaknya tugas akademik kampus membuat mereka harus mampu mengimbanginya dengan baik. Sebagai mahasantri mereka harus telaten, sabar dan tekun demi mencapai kesuksesan dan cita-citanya. Oleh karena itu, mereka harus meyakini setiap kemampuan yang ada pada diri mereka, baik dalam hal tugas akademik kampus maupun pesantren. Dengan begitu self-efficcy tinggi akan muncul dan berkembang dalam diri mereka sehingga mempermudah dalam menggapai kesuksesannya.

Dalam menuntut ilmu setiap orang pasti menjumpai permasalahan dalam kehidupan kesehariannya. Permasalahan tersebut harus dipecahkan karena sudah menjadi tuntutan dan tanggung jawab sebagai seorang mahasiswa. Mereka harus memiliki keyakinan diri yang kuat dalam menghadapi setiap permasalahan yang terjadi. Dengan keyakinan dan tekad yang kuat akan menjadi faktor yang berpengaruh dalam mencapai tujuan yang dinginkannya terhadap keberhasilan mahasantri dalam menuntaskan tuntutan akademik, baik di pesantren maupun di kampus. Mahasantri pemilik self-efficacy tinggi akan mempunyai pandangan untuk terus optimis terhadap potensi mereka yakin mampu menyelesaikan tugas-tugasnya dalam aktivitas kesehariannya. Kesiapan keyakinan para mahasantri dalam mengatasi masalah di kampus maupun di pondok pesantren sangat berpengaruh dan membantu demi tercapainya kelangsungan hidup mahasantri. Self-efficacay yang tinggi sangat dibutuhkan sehingga memudahkan para mahasantri untuk menghadapi setiap permasalahannya yang sedang terjadi. Sebagaimana kalam Allah yang menjelaskan tentang kemantapan diri terkandung dalam surah Ali 'Imran ayat 139:

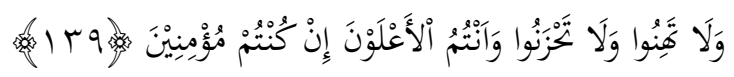

Jangan kamu bersikap lemah, dan janganlah (pula) kamu bersedih hati, padahal kamulah orang-orang yang paling tinggi (derajatnya), jika kamu orang-orang yang beriman.

Tafsir surah tersebut menerangkan sesungguhnya Allah telah menciptakan manusia sesempurna mungkin dengan kelebihannya masing-masing dibanding makhluk Allah lainnya. Sehingga manusia diharapkan memiliki keyakinan dan mampu dalam menyelesaikan setiap permasalahan apapun dengan semua kelebihan yang telah dianugerahkan oleh Allah SWT (Shihab, 2007).

Self-efficacy dapat dapat memberikan efek dengan tendensi bahwa self-efficacy mampu ditingkatkan, dirubah, diperoleh dari pengalaman penguasaan kinerja, kebiasaan seseorang, ajakan sosial dan penyemangat emosi (Bandura, 1997). Pernyataan ini didasarkan dalam penelitian terdahulu, yang dilaksanakan oleh Marsela dkk menunjukkan bahwa upaya peningkatan self-efficacy dapat menggunakan salah satu sumber yang berpengaruh yaitu pengalaman orang lain (vicarious experience) (Marsela et al., 2020). Artinya self-efficacy mampu ditingkatkan dengan adanya proses bimbingan kelompok melalui pemodelan atau peniruan model teknik modelling. Dengan begitu self-efficacy seseorang dapat meningkat dengan cara melihat atau mengamati orang lain yang memiliki kapasitas yang sesuai dengan dirinya dalam mencapai keberhasilan.

Untuk meningkatkan self-efficacy diperlukan sebuat metode untuk membantu meningkatkannya, seperti pemberian bantuan bimbingan dan konseling yang mampu membantu seseorang ketika mengatasi setiap problematika yang muncul dalam diri individu. Sebagaimana fokus pencapaian bimbingan dan konseling yaitu menolong seseorang dalam upaya meningkatkan dirinya secara optimal dalam mencapai tujuan hidupnya sesuai dengan tahap perkembangannya (Ramlah, 2018). Kegiatan bimbingan dan konseling biasanya dilakukan dengan cara individu ataupun kelompok. Secara individu atau perorangan biasanya pelayanan diberikan secara konseling individu atau melakukan konsultasi, kemudian secara berkelompok dapat dilakukan dengan bimbingan kelompok atau konseling kelompok (Folastri \& Rangka, 2016). Penggunaan layanan bimbingan kelompok dalam penelitian ini dirasa mampu meningkatkan efikasi diri mahasantri. Dengan alasan bahwa penggunaan layanan bimbingan kelompok ini diharapkan seseorang 
mampu memperoleh perilaku baru, membuang perilaku lamanya melalui model yang telah ditunjukkan dengan dinamika kelompok.

Bimbingan kelompok sendiri dapat diartikan sebagai suatu layanan yang digunakan untuk pengembangan diri seseorang dilakukan secara berkelompok yang terencana dan terorganisasi. Kemudian bimbingan kelompok juga menjadi pilihan diberbagai latar sekolah, perguruan tinggi, masyarakat, lembaga pemerintah hingga lembaga masyarakat luas. Hal ini mengacu bahwa bimbingan kelompok sendiri jika dilihat dari sisi kuantitas, sisi efisiensi, sisi strategi, sisi kualitas dan efektivitas, dan sisi materinya sangat mudah diaplikasikan dalam hal apapun. Misalnya dari segi kualitas, dapat memudahkan konselor dalam penggunaan dinamika kelompok yang memberikan ketentuan secara konstruktif sampai tujuan dari layanan bimbingan kelompok berjalan lancar. Dari segi materipun bimbingan kelompok mampu menyesuaikannya dengan kebutuhan anggota kelompok berdasarkan kesepakatan bersama (Folastri \& Rangka, 2016).

Pada umumnya bimbingan kelompok menggunakan konsep dinamika kelompok, yaitu teknik yang melibatkan anggota kelompok seperti sosial drama, bermain peran dan semua gaya atau perlakuan lainnya. Teknik modelling merupakan diantara proses layanan yang melibatkan kelompok. Teknik Modelling merupakan proses mencontoh tingkah laku dan tatakrama orang lain, yang terdapat pemodelan sehingga model tersebut dapat untuk dicontoh dan dipraktekkan. Ada beberapa macam penokohan atau Modelling yaitu: pemodelan langsung, pemodelan secara simbolik, pemodelan ganda (multiple model) (Gunarsa, 2004). Ke tiga jenis teknik modelling, peneliti menggunakan jenis Modelling simbolik (symbolic model) dan penokohan ganda (multiple model). Teknik modelling simbolik adalah pemodelan dengan mencontoh model melalui film atau video yang kemudian mereka diajak untuk menyelami model sehingga dapat dicontoh atau ditirukan (Komalasari, 2011). Sedangkan penokohan ganda (multiple model) dapat dilakukan dengan cara mengamati model dan mempraktikkannya sehingga mampu merubah, mengamati ataupun mempelajari perilaku baru. Kedua teknik ini digunakan peneliti untuk meningkatkan self-efficacy mahasantri agar mahasantri mampu memperoleh gambaran, meniru, memilih atau megurangi perilaku dari model yang ditampilkan mengenai self-efficacy atau keyakinan diri yang baik.

Pemilihan perlakuan atau treatment bimbingan kelompok teknik modelling pada penelitian ini didasarkan pada penelitian terdahulu. Penelitian yang dilaksanakan oleh Lestari menunjukkan bahwa selfefficacy dapat ditngkatkan melalui layanan bimbingan kelompok teknik modelling simbolis (Lestari, 2014). Kemudian berdasarkan penelitian terdahulu menjelaskan bahwa pemberian perlakuan bimbingan kelompok memiliki keefektifan sehingga mampu menambah tingginya self-efficacy siswa (Putra et al., 2013).

Sebagaimana eksperimen terkenalnya milik Albert Bandura, yakni percobaan yang sering dikenal dengan percobaan boneka bobo doll. Percobaan ini dilakukan oleh dua orang anak yang diperlakukan berbeda. Mereka masing-masing diberikan satu buah boneka besar dan diberikan tontonan film yang berbeda. Yang satu diberikan tontonan film laga dan yang satu tidak. Sesaat kemudian anak yang diberi tontonan film laga menirukan semua tingkah laku atau tindakan pada film tersebut, sedangkan anak tanpa diperlihatkan film laga hanya diam (Subandriyo \& Faishol, 2019). Hal ini membuktikan bahwa sebagian besar perilaku seseorang berasal dari meniru sehingga seseorang mampu menemukan dan mempelajari tingkah laku baru. Karena pada dasarnya self-efficacy secara langsung maupun tidak dapat terwujud setelah proses pengamatan. Hal ini menimbulkan asumsi dari peneliti bahwa teknik modelling mampu meningkatkan self-efficacy mahasantri yang rendah. Untuk itu, teknik Modelling ini memiliki peran penting dan diperlukan untuk meningkatkan efikasi diri (Self-efficacy) dari tiap individu dalam menghadapi permasalahan-permasalahan pada diri mahasantri. Selain itu dengan adanya layanan tersebut dapat mengubah persepsi mahasantri terhadap kurangnya keyakinan dan ketidakmampuan terhadap dirinya sendiri, sehingga mereka mampu mengoptimalkan diri untuk meningkatkan produktifitas dan mengambil keputusan sesuai dengan keinginannya.

\section{Metode}

Lokasi penelitian ini dilaksanakan di salah satu pesantren mahasiswa di Tulungagung yaitu Pondok Pesantren Tahfidzul Qur'an Al-Hidayah Tulungagung. Pendekatan penelitian ini menggunakan pendekatan kuantitatif metode penelitian eksperimen. Desain penelitian menggunakan Quasi Experimental Design jenis Nonequivalent control group design. Pada proses pemilihan sampel, peneliti memakai jenis Non-Probability Sampling dengan memilih teknik sampling berupa Purposive Sampling. Pemilihan teknik sampling ini bertujuan untuk mempertimbangkan beberapa aspek tertentu. Maksudnya sampel yang dipilih melalui proses karakteristik yaitu tidak didasarkan tingkatan, tetapi dipilih sesuai dengan adanya sebuah maksud tertentu (Sugiyono, 2019). Teknik ini digunakan karena tidak semua subjek diambil dan dijadikan sampel penelitian. Peneliti akan memilih subjek yang memiliki self-efficacay sedang dan rendah. 
Jumlah total keseluruhan untuk populasi yaitu seluruh mahasantri dengan status masih menjadi mahasiswa. Ketentuan pengambilan sampel disesuaikan dengan kebutuhan penelitian yaitu memberikan ketentuan tertentu diantaranya, mahasantri dengan rentang usianya 18-24 tahun atau masih aktif menjadi mahasiswa dan teridentifikasi sebagai mahasantri dari semua jurusan dan semester yang memiliki self-efficacy dalam kategori sedang dan rendah. Pertimbangan pemilihan sampel didasarkan pada fase dimana mereka diharuskan memiliki self-efficacy tinggi guna membantu mengoptimalkan diri dalam meyakini setiap kemampuan yang dimiliki dari berbagai polemik yang ada. Sampel dalam penelitian ini sebanyak 12 mahasantri, sesuai dengan jenis penelitian ini sampel tersebut akan dibagi rata menjadi kelompok eksperimen dan kontrol. Pada kelompok eksperimen akan diberikan treatment berupa teknik modelling sedangkan pada kelompok kontrol tidak diberikan perlakuan atau treatment. Terakhir akan diberikan posttest pada ke dua kelompok guna melihat perbedaan dan melihat seberapa besar pengaruh treatment pada selfefficacy mahasantri.

\section{Hasil dan Pembahasan}

Tingkat Self-efficacy mahasantri Pondok Pesantren Tahfidzul Qur'an Al-Hidayah Tulungagung bisa terbilang masih ada di lingkup pesantren. Peran ganda yang mereka jalani sebagai mahasantri tahfidz kerap membuat mereka kurang yakin akan kemampuan mengerjakan berbagai aktifitas di pondok maupun di kampus. Berdasarkan hasil wawancara yang telah dilakukan peneliti dengan beberapa mahasantri bahwa permasalahan yang sering mereka alami adalah rasa malas yang muncul secara tiba-tiba, sering menundanunda pekerjaan baik tugas kampus atau pesantren, kurang bisa membagi waktu menghindari tugas yang sulit. Berbagai polemik yang dialami mahasantri ini membuktikan bahwa self-efficacy mahasantri terbilang masih rendah.

Individu dengan self-efficacy yang tinggi tidak akan menunda-nunda dan akan tanggap dalam pengerjaan tugas meskipun tugas tersebut sulit. Tapi sebaliknya jika mereka memiliki self-efficacy rendah pada pengerjaan tugas, mereka akan suka menunda-nunda pengerjaan tugas sampai tugas tersebut akan dikumpulkan. Mereka akan memandang tugas sebagai beban yang besar bahkan mereka juga tidak mau mencari jalan keluar dari permasalahannya tersebut. Ketika menghadapi permasalahan, mereka cenderung lebih banyak mengeluh dari pada bekerja mencari jalan keluar. Terkadang hal seperti inilah yang memunculkan rasa putus asa pada diri mereka karena self-efficacy nya rendah (Bandura, 1994).

Rendahnya self-efficacy pada diri mahasantri tentunya akan berpengaruh terhadap kelangsungan hidup mereka. Sebagai mahasantri mereka dituntut untuk mengoptimalkan diri mereka untuk mencapai kesuksesan dalam mencari ilmu. Seseorang yang memiliki keyakinan dalam pengerjaan tugas, mereka akan mempunyai peluang lebih besar dalam pencapaiannya menyelesaikan tugas dengan mudah dibandingkan mereka yang kurang yakin terhadap kemampuannya (Alwisol, 2009). Artinya seseorang dengan keyakinan dan keperpercayaan terhadap kemamapuannya akan lebih memiliki peluang besar untuk menggapai keberhasilan yang dituju. Karena pada dasarnya self-efficacy memiliki beberapa aspek seperti kognitif, motivasi, seleksi dan afeksi yang akan membantu mengoptimalkan diri dalam meningkatkan self-efficacy (Corsini, 1994).

Self-efficacy dipengaruhi oleh tiga aspek yaitu: tingkat kesulitan tugas (magnitude), kemantapan keyakinan (strenght) dan luas bidang perilaku (generality) (Suseno, 2009). Dari ketiga kriteria yang dijelaskan Bandura, kemudian peneliti mengembangkannya menjadi instrumen penelitian berupa angket. Peneliti membuat angket sebanyak 44 butir soal yang kemudian disebarkan kepada 30 mahasantri diberbagai kampus sebagai sampel uji coba dengan hasil tersisa 30 butir soal. Setelah memperoleh hasil yang valid, angket kemudian disebarkan kepada 20 mahasantri yang akan dijadikan sampel penelitian. Berdasarkan hasil nilai pre-test skala self-efficacy yang diberikan 20 mahasantri menunjukkan bahwa terdapat 12 anak yang masuk kategori sedang dan rendah dengan rincian 4 mahasantri masuk kategori rendah dan 8 mahasantri masuk kategori sedang, kemudian 8 mahasantri terhitung dalam kategori tinggi.

Berdasarkan uji validitas, dengan jumlah sampel uji coba sebanyak 30, maka diperoleh R Tabel 0,361 dengan taraf kesalahan 5\%, sehingga dapat disimpulkan R Hitung $>\mathrm{R}$ Tabel dinyatakan valid. Dari 44 nomor item ada 14 nomor item tidak benar dan tersisa 30 nomor item valid. Kemudian dilakukan uji reliabilitas Cronbach's Alpha dengan ketentuan nilai Cronbach's Alpha > 0,6 sehingga data dianggap reliabel (Sekaran, 2009). Pada perolehan hitung uji reliabilitas dengan nilai 0,921 > 0,6 sehingga data dinyatakan reliabel.

Pada pengujian uji hipotesis untuk dapat melihat data termasuk parametrik atau non parametrik selanjutnya diperlukan uji asumsi dasar berupa uji homogenitas dan uji normalitas (Arikunto, 2006). Uji normalitas berguna menilai kebenaran data sehingga datanya juga harus normal dan dapat digunakan. Pengukuran untuk melihat data layak digunakan dan data berkonstribusi normal pada taraf signifikansi data 
yaitu $>0,05$ dan ketika taraf signifikansinya $<0,05$ sehingga data tersebut tidak dapat digunakan atau data tidak berkonstribusi normal.

Tabel 1. Output Uji Normalitas

\begin{tabular}{cccccccc}
\hline \multicolumn{9}{c}{ Tests of Normality } \\
\hline \multicolumn{1}{c}{ Kolmogorov-Smirnov ${ }^{\mathrm{a}}$} & \multicolumn{3}{c}{ Shapiro-Wilk } \\
\hline KELAS & Statistic & Df & Sig. & Statistic & Df & Sig. \\
\hline Pre_Eksperimen & 0.263 & 6 & $.200^{*}$ & 0.871 & 6 & 0.230 \\
\hline Post_Eksperimen & 0.222 & 6 & & $.200^{*}$ & 0.896 & 6 & 0.351 \\
\hline Pre_Kontrol & 0.173 & 6 & $.200^{*}$ & 0.951 & 6 & 0.749 \\
\hline Post_Kontrol & 0.251 & 6 & & $.200^{*}$ & 0.895 & 6 & 0.346 \\
\hline
\end{tabular}

Sumber: Statistical Package for Sosial Science (SPSS) versi 26.

Pada tabulasi hitung uji normalitas dapat diketahui hasil perolehan seluruh data untuk kelas eksperimen dan kelas kontrol perolehan data pre-test maupun post-test menyatakan bahwa nilai sig Kolmogorov Smirnov dan Shapiro Wilk $>0.05$. Maka dapat diambil kesimpulan pengujian ini telah menghasilkan data normal atau $\mathrm{H}_{\mathrm{a}}$ diterima.

Tabel 2. Output Uji Homogenitas

\begin{tabular}{|c|c|c|c|c|c|}
\hline \multicolumn{6}{|c|}{ Test of Homogeneity of Variances } \\
\hline & & Levene & df1 & df2 & Sig. \\
\hline & & Statistic & & & \\
\hline \multirow[t]{4}{*}{ HASIL } & Based on Mean & 2.988 & 1 & 10 & 0.115 \\
\hline & Based on Median & 2.832 & 1 & 10 & 0.123 \\
\hline & $\begin{array}{l}\text { Based on Median and } \\
\text { with adjusted df }\end{array}$ & 2.832 & 1 & 8.926 & 0.127 \\
\hline & Based on trimmed mean & 2.986 & 1 & 10 & 0.115 \\
\hline
\end{tabular}

Sumber:Statistical Package for Sosial Science (SPSS) versi 26.

Berdasarkan hasil tabel hitung uji homogenitas ditemukan nilai hitung sig Based on Mean $0.115>$ 0.05 , kemudian bisa diartikan hasil perolehan pada kelompok eksperimen dan kelompok kontrol adalah sama atau homogen, sehingga data dapat digunakan.

Pada pengujian hipotesis dilakukan memakai uji Paired sample T-test dengan maksud guna melihat perbandingan keadaan nilai rata-rata pre-test dan post-test mahasantri pada ke dua kelompok dengan treatment dan sebaliknya. Sehingga diperoleh nilai signifikansi (2-tailed) $<0.05$ artinya terdapat pengaruh pada ke dua variabel yang signifikan.

Tabel 3. Output Uji Paired Sample T Test

\begin{tabular}{|c|c|c|c|c|c|c|c|c|c|}
\hline \multicolumn{10}{|c|}{ Paired Samples Test } \\
\hline & & & Paired & ifferenc & & & & & \\
\hline & & \multirow[t]{2}{*}{ Mean } & \multirow[t]{2}{*}{$\begin{array}{c}\text { Std. } \\
\text { Deviation }\end{array}$} & \multirow[t]{2}{*}{$\begin{array}{l}\text { Std. } \\
\text { Error } \\
\text { Mean }\end{array}$} & \multicolumn{2}{|c|}{$\begin{array}{l}95 \% \text { Confidence } \\
\text { Interval of the } \\
\text { Difference }\end{array}$} & \multirow[t]{2}{*}{$\mathrm{t}$} & \multirow[t]{2}{*}{ df } & \multirow[t]{2}{*}{$\begin{array}{l}\text { Sig. (2- } \\
\text { tailed) }\end{array}$} \\
\hline & & & & & Lower & Upper & & & \\
\hline Pair 1 & $\begin{array}{l}\text { Pre-Eksperimen } \\
\text { Post-Eksperimen }\end{array}$ & -34.167 & 5.269 & 2.151 & -39.697 & -28.637 & -15.882 & 5 & 0.000 \\
\hline Pair 2 & $\begin{array}{l}\text { Pre-Kontrol } \\
\text { Post-Kontrol }\end{array}$ & -1.667 & 1.366 & 0.558 & -3.100 & -0.233 & -2.988 & 5 & 0.031 \\
\hline
\end{tabular}

Sumber:Statistical Package for Sosial Science (SPSS) versi 26.

Berdasarkan nilai Pair 1 didapatkan nilai sig (2 tailed) sebesar 0,000 $<0,05$ maka bisa diartikan terlihat perbandingan pada nilai baik pre-test dan post-test kelompok eksperimen. Maka menghasilkan keputusan bimbingan kelompok teknik modelling memiliki sumbangsih pengaruh terhadap selfeefficacy mahasantri. 
Selanjutnya pada pengujian uji independent sample t test yang diperuntukkan mengamati perbedaan nilai rata-rata post-test kelompok eksperimen dan kelmpok kontrol setelah diberikan perlakuan dan yang tidak diberikan perlakuan. Berikut tabulasi perhitungan uji hipotesis pada kedua kelompok eksperimen dan kelompok kontrol:

Tabel 4. Output Uji Independent Sample T Test

\begin{tabular}{|c|c|c|c|c|c|c|c|c|c|c|}
\hline \multicolumn{11}{|c|}{ Independent Samples Test } \\
\hline & & \multicolumn{2}{|c|}{$\begin{array}{l}\text { Levene's Test } \\
\text { for Equality } \\
\text { of Variances }\end{array}$} & \multicolumn{7}{|c|}{ t-test for Equality of Means } \\
\hline & & \multirow[t]{2}{*}{$\mathrm{F}$} & \multirow[t]{2}{*}{ Sig. } & \multirow[t]{2}{*}{$\mathrm{T}$} & \multirow[t]{2}{*}{ Df } & \multirow[t]{2}{*}{$\begin{array}{l}\text { Sig. } \\
(2- \\
\text { tailed })\end{array}$} & \multirow[t]{2}{*}{$\begin{array}{c}\text { Mean } \\
\text { Difference }\end{array}$} & \multirow[t]{2}{*}{$\begin{array}{l}\text { Std. Error } \\
\text { Difference }\end{array}$} & \multicolumn{2}{|c|}{$\begin{array}{l}95 \% \text { Confidence } \\
\text { Interval of the } \\
\text { Difference }\end{array}$} \\
\hline & & & & & & & & & Lower & Upper \\
\hline \multirow{2}{*}{ Hasil } & $\begin{array}{c}\text { Equal } \\
\text { variances } \\
\text { assumed }\end{array}$ & 2.988 & 0.115 & 4.907 & 10 & 0.001 & 23.000 & 4.687 & 12.557 & 33.443 \\
\hline & $\begin{array}{c}\text { Equal } \\
\text { variances not } \\
\text { assumed }\end{array}$ & & & 4.907 & 9.030 & 0.001 & 23.000 & 4.687 & 12.403 & 33.597 \\
\hline
\end{tabular}

Sumber:Statistical Package for Sosial Science (SPSS) versi 26.

Perolehan hasil tabulasi didapatkan nilai sig ( 2 tailed) sebesar $0.001<0.05$, maka dapat diketahui ada perbedaan nilai rata-rata self-efficacy mahasantri. Maka dapat diperoleh hasil signifikan perbedaan pada nilai rata-rata hasil post-test kelompok eksperimen dan kontrol. Perolehan nilai output independent statictic diketahui jumlah data hasil perolehan nilai post-test kelompok eksperimen mean sebanyak 103.50 dan untuk kelompok kontrol sebanyak 80.50. Maka dapat disimpulkan terdapat perbedaan nilai post-test kelompok eksperimen dan kontrol, sehingga self-efficacy mahasantri dapat ditingkatkan setelah mendapatkan perlakuan teknik modelling.

Sementara pada uji $N$-Gain Score dilakukan guna melihat tingkat efektivitas, seberapa efektifkah bimbingan kelompok teknik modelling untuk meningkatkan self-efficacy mahasantri:

Tabel 5. Hasil Perhitungan Uji N-Gain Score

\begin{tabular}{cccc}
\hline Konseli & Kel Eksperimen & Konseli & Kel Kontrol \\
\cline { 2 - 2 } & N Gain Score (\%) & & N Gain Score (\%) \\
\hline FZ & 207.14 & M & 12.50 \\
\hline DTA & 88.1 & LA & 0 \\
\hline SNH & 144.44 & INY & 16.67 \\
\hline UZF & 95 & RA & 0 \\
\hline IRL & 84.09 & TNA & 10.71 \\
\hline RH & 146.15 & YS & 6.67 \\
\hline Rata-rata & 127.4879 & Rata-rata & 0,03 \\
\hline Minimal & 84.09 & Minimal & 0 \\
\hline Maksimal & 207.14 & Maksimal & 16.67 \\
\hline Sumber:Statistical Package for Sosial Science (SPSS) versi 26. &
\end{tabular}

Hasil tabulasi uji $N$ Gain Score memperlihatkan nilai pada uji $N$-Gain score kelompok eksperimen $127.4879 \%$ masuk pada kategori tinggi, nilai minimal 84.09 \% dan nilai maksimal 207.14 \%. Maka dari itu berdasarkan uji $N$-Gain score pada kelompok eksperimen dengan teknik modelling memperoleh score tinggi dibanding kelompok kontrol tanpa adanya perlakuan. Dapat diartikan bimbingan kelompok teknik modelling memiliki keefektifan dalam meningkatkan self-efficacy mahasantri.

Hasil akhir menunjukkan bahwa bimbingan kelompok teknik modelling memberikan pengaruh yang signifikan terhadap self-efficacy mahasantri yang dibuktikan pada perbedaan nilai pre-test dan post-test pada ke dua kelompok. Perilaku mahasantri yang menggambarkan self-efficacy rendah seperti malas dalam menghafal, menunda-nunda dalam mengerjakan tugas, menghindari tugas yang sulit mengalami penurunan 
setelah mendapatkan perlakuan bimbingan kelompok teknik modelling. Penggunaan teknik modelling dirasa bisa memberikan sumbangsih untuk menuntaskan permasalahan dan membantu mahasantri memperoleh perilaku baru dari tokoh yang memerankan dalam video kemudian dapat menirunya untuk dijadikan patokan ke arah yang lebih positif pada kehidupan mahasantri. Sehingga mahasantri dapat mencontoh ataupun mengurangi perilaku mereka sehingga dapat mengokohkan perilaku yang sudah tertata kemudian mengurangi perilaku yang kurang baik untuk membentuk perilaku baru. Tujuan teknik modelling sendiri adalah untuk mengajarkan konseli memilih perilaku sesuai dengan keinginannya dan melatih kepekaan sosial melalui modelling melalui gambar atau tanda-tanda dari objek aslinya (Abimanyu, 2006).

Pada proses pelaksanaan layanan bimbingan kelompok peneliti melaksanakan sesuai sesuai dengan buku pedoman yang telah dibuat, yakni pelaksanaan bimbingan kelompok dilakukan 5 kali pertemuan. Materi-mteri pada setiap pertemuan dilakukan sesuai dengan aspek self-efficacy dengan menggunakan dua macam teknik modelling yaitu multiple model dan symbolic model. Untuk multiple model subjek diajak untuk memperhatikan dan mengamati salah satu anggota kelompok yang sedang memperagakan untuk meniru atau mengambil perilaku baru. Sedangkan untuk symbolic model subjek akan diajak untuk melihat dan mengamati video yang telah disediakan. Kemudian mereka diajak memperagakan apa yang telah mereka lihat dan mengutarakan pesan yang diambil setelah menonton video tersebut. Kemudian dari setiap pertemuan peneliti juga melakukan evaluasi dengan tujuan agar mahasantri mampu secara maksimal menerapkan self-efficacy pada diri mereka serta melihat perkembangan yang lebih baik.

Penelitian ini didukung oleh hasil penelitian sebelumnya yang dilakukan oleh (Syamsudin, 2017). Penelitiannya yang telah dilakukan Syamsudin dapat disimpulkan bahwa teknik modelling dalam bimbingan kelompok berpengaruh dalam meningkatkan kepercayaan diri peserta didik. Dengan teknik modelling, individu mampu mengoptimalkan dirinya untuk lebih percaya diri dan menghilangkan pikiran negatif dalam diri individu. Penelitian lainnya yang sejalan dengan penggunaan teknik modelling adalah penelitian yang dilakukan oleh (Chairunnisya, 2019). Pada penelitian tersebut diperoleh hasil bahwa konseling kelompok behaviour dengan teknik modelling berpengaruh dalam meningkatkan efikasi diri peserta didik. Kemudian penelitian lainnya yang sejalan dilakukan oleh (Mardhatillah, 2020). Pada penelitian tersebut memperoleh hasil bahwa bimbingan kelompok dengan teknik modelling efektif meningkatkan self-esteem siswa. Dengan begitu, teknik modelling menjadi pilihan dalam membantu permasalahan individu yang bersifat menyeluruh.

\section{Kesimpulan}

Proses layanan bimbingan kelompok pada mahasantri dengan metode teknik modelling mampu meningkatkan self-efficacy mahasantri Pondok Pesantren Tahfidzul Qur'an Al-Hidayah Tulungagung. Perolehan presentase menunjukkan pada uji paired sampel t test, pada output pair 1 menghasilkan nilai sig (2 tailed) sebesar $0,000<0,05$ sehingga diambil kesimpulan ada perbandingan nilai pre-test dan post-test kelompok eksperimen. Hasil tersebut membuktikan jika bimbingan kelompok teknik modelling memiliki sumbangsih tinggi terhadap self-efficacy mahasantri. Pada uji independent sample t test memperoleh nilai sig (2 tailed) $0.001<0.05$, diartikan ada perbedaan nilai rata-rata self-efficacy mahasantri setelah pemberian posttest bak pada kelompok eksperimen dan kelompok kontrol. Sedangkan dari uji $N$ Gain Score menghasilkan nilai rata-rata $N$-Gain score pada kelompok eksperimen sebesar $127.48 \%$ masuk pada kategori tinggi, nilai minimal $84.09 \%$ dan nilai maksimal $207.14 \%$. Nilai rata-rata $N$-Gain Score kelompok kontrol $0.03 \%$ masuk pada kategori rendah, nilai minimal $0 \%$ dan nilai maksimal $16.67 \%$. Sehingga dapat diketahui dari hasil uji $N$-Gain score nilai rata-rata kelompok eksperimen dengan perlakuan teknik modelling mendapat score tinggi dibanding nilai rata-rata kelompok kontrol tanpa diberikan perlakuan. Dapat diperoleh hasil akhir yaitu bimbingan kelompok teknik modelling memiliki pengaruh, mempunyai sumbangsih tinggi dalam meningkatkan self-efficacy mahasantri Pondok Pesantren Tahfidzul Qur'an Al-Hidayah Tulungagung.

\section{Referensi}

Abimanyu, S. dan T. M. (2006). Teknik Dan Laboratorium Konseling. Depdiknas.

Alwisol. (2009). Psikologi kepribadian. UMM Press.

Arikunto, S. (2006). Prosedur Penelitiam Suatu Pendekatan Praktik. Rineka Cipta.

Bandura, A. (1994). self-efficacy. In V. S. Ramaghaudran (Ed), Encyclopedia o human behavior. Academic Press. Bandura, A. (1997). Self-Efficacy The Exercise Of Control. W.H Freeman and Company.

Chairunnisya. (2019). Pengaruh Konseling Kelompok Behaviour Dengan Teknik Modelling Dalam Meningkatkan Efikasi Diri Peserta Didik Kelas Xi.

Corsini, R. . (1994). Encyclopedia of Psychology. Jhon Wiley and Son. 
Folastri, S., \& Rangka, B. I. (2016). Prosedur Layanan Bimbingan dan Konseling Kelompok (Panduan Praktis Menyeluruh) (Issue January 2016).

Gunarsa, S. D. (2004). Pskologi Praktis. PT. BPK gunung mulia.

Hurlock, E. B. (2003). Psikologi Perkembangan. Erlangga.

Komalasari, gantina dkk. (2011). Teori dan teknik konseling. PT indeks.

Lestari, I. P. K. (2014). Upaya Meningkatkan Self Efficacy Rendah Terhadap Pemilihan Karir Dengan Konseling Behaviour Teknik Modeling Simbolik Pada Siswa Kelas VIII E Di SMPN N 6 Batang.

Lestari, W. P., \& Afifah, D. R. (2016). Pengaruh Self Efficacy Dan Kecerdasan Emosi Terhadap Motivasi Berprestasi Siswa Smk Pgri 1 Madiun. Counsellia: Jurnal Bimbingan Dan Konseling. https://doi.org/10.25273/counsellia.v4i2.263

Mardhatillah, R. (2020). Efektivitas Bimbingan KelompokDengan Teknik Modelling Untuk Meningkatkan SelfEstem Siswa Di Sekolah Menengah Atas Negeri 6 Pekanbaru.

Marsela, I., Rosra, M., \& Andriyanto, R. E. (2020). Peningkatan Efikasi Diri melalui Konseling Kelompok Teknik Modeling pada Siswa SMP. ALIBIKIN (Jurnal Bimbingan Konseling), 8(2). jurnal.fkip.unila.ac.id

Navion, F. P. (2016). Febranti putri navion. 03, 111-120.

Nelson Jones, R. (2011). Teori Dan Praktik Konseling Dan Terapi. Pustaka Pelajar.

Putra, S. A., Daharnis, D., \& Syahniar, S. (2013). Efektivitas Layanan Bimbingan Kelompok dalam Meningkatkan Self Efficacy Siswa. Konselor, 2(2), 1-6. https://doi.org/10.24036/02013221399-0-00

Ramlah. (2018). Pentingnya layanan bimbingan konseling bagi peserta didik. Al-Mau'Izhah, 1(September), 70-76. https://jurnal.umpar.ac.id/index.php/mauizhah/article/download/8/6/

Sekaran, U. (2009). Metode Penelitian Untuk Bisnis. Salemba Empat.

Shihab, M. Q. (2007). Tafsir Al Misbah Jilid 1-15. Lentera Hati.

Subandriyo, \& Faishol, R. (2019). Tadrisuna Tadrisuna. 2(1), 1-13.

Sugiyono. (2019). Metode Penelitian Kuantitatif, Kualitatif dan R\&D. Alfabeta.

Suseno, M. N. (2009). Pengaruh Pelatihan Komunikasi Interpersonal Terhadap Efikasi Diri Sebagai Pelatih pada Mahasiswa. Jurnal Intervensi Psikologi, 1.

Syamsudin. (2017). Teknik Modelling Dalam Bimbingan Konseling Untuk Meningkatkan Kepercayaan Diri Peserta Didik Kelas VII G SMP PGRI 6 BANDAR LAMPUNG. 